\title{
Governing buyers of sex in the People's Republic of China
}

(C) Elaine Jeffreys 2005

University of Technology, Sydney

\begin{abstract}
This paper examines the developing body of Chinese prostitution law, and the nature of its implementation, with reference to the media controversy surrounding the case of a male academic penalized as a buyer of commercial sexual services in late 2004 . It argues that the protagonist's highly public 'fall from grace' may owe more to the Chinese media's new capacity to act as part of a disciplinary apparatus that extends beyond the purview of the Party-state-via its claim to promote freedom of information - than the presumed repressive ethos of the Chinese Communist Party.
\end{abstract}

Keywords: China; prostitution debates; governance; media.

The biography of Lu Deming, as presented on the website of Shanghai's prestigious Fudan University, depicts a man with a history of outstanding scholarly achievement, and by implication, high moral and social standing. Born on 20 April 1957, in Jiangsu

Province, Lu was among the first group of students to enter Fudan University in 1977, following the disruption caused to China's higher education system by the Great Proletarian Cultural Revolution. ${ }^{1}$ After completing a Bachelor and Masters degree, he became a teacher at Fudan in 1984. Between 1988-99, he acted as Head of the China Centre for Economic Studies and, concurrently, as Vice-Dean of the School of Economics from 1996-9. In 1995, Lu Deming was promoted to the position of professor for his extraordinary achievements. In addition to teaching undergraduate and

\footnotetext{
${ }^{1}$ The Cultural Revolution is now dated as lasting from 1966-76 and described as '10 years of chaos'. During the early stages of this period, Chinese universities and schools were closed while students engaged in 'revolution'. Despite considerable local variation, the return to 'normal life' and the re-establishment of exam-based entrance to universities is said to have begun in late 1976, following the death of Chairman Mao Zedong.
} 
postgraduate students, he has acted as a consultant for various government and corporate bodies, including: the Shanghai Bureau of Industrial and Commercial Administration; the Yunnan Provincial Government; and the Construction Bank of China. He has also acted as Head of the Taiwan Economic Research Centre and Co-President of the Hong KongShanghai Development Institute (School of Economics (n.d.); Yu 2004).

This biography was sullied irrevocably in late 2004 when Lu Deming became exposed to public scandal as the central protagonist in what the Chinese media described as the 'whoring professor case’ or the 'Lu Deming Incident' (hereafter the Incident). According to press statements released in early November by the Publicity Department of Fudan University’s Communist Party Committee and subsequently by Lu Deming himself, on 1 September 2004, Lu was stripped of his Party membership, removed from his then existing position as Dean of Economics and discharged from his teaching posts, and his professorial privileges were suspended for a period of three years ('Fudan jingji xueyuan yuanyuanzhang Lu Deming fabiao shengming gongkai rencuo’2004; He 2004). Relevant Party and administrative committees at Fudan imposed these penalties following Lu's apprehension by the Chinese police on 12 August for participation in the banned practice of prostitution. The professed rationale for releasing the two press statements was to clarify the details of the case and thereby halt public outcry regarding its nature and handling. This outcry flowed from widespread speculation about the case on China's burgeoning new media of the Internet, with concerned 'netizens' debating the Incident from late August onwards (Niu and Chen 2004), whereas the first print media report did not appear until 1 November (Guo, J. 2004).

Although some media commentators have criticized the governmental handling of the Incident for precipitating an ignominious end to an otherwise exemplary career, and signifying an unnecessary intrusion into the private domain of the sexual (Ji 2004), there is more at stake here than this 'liberal' reading allows. Lu Deming's transformation from a virtual 'nobody' into a notorious national figure (even a contemporary anti-hero) can be viewed as the apotheosis of a hitherto unparalleled nexus between the governmental rationalities of the Chinese Communist Party (CCP), the legal system, the media, and a 
global public in present-day China. Indeed, as an insight into the complex interaction between different disciplinary apparatuses in the PRC, the case is probably unprecedented, the sheer banality of the details making it even more extraordinary.

What remains of this paper is divided into four sections. The first section contextualizes the controversial nature of the Incident with reference to the developing body of China's prostitution law. The second section suggests that the Incident became a national scandal following the release of press statements designed to justify the internal rulings of Fudan University and the personal conduct of Lu Deming respectively. The third section examines the ensuing public debate and shows how it raises the question of what government - understood as the 'conduct of conduct' - means in the current Chinese context, especially in relation to the living tensions between what might be described as liberal and Maoist approaches to governance and the law, and associated conceptions of the 'public' and 'private' realms, the role of public intellectuals qua professionals and qua moral leaders, and the liberality (or 'illiberality') of the media. It concludes that Lu Deming's 'fall from grace' owes more to the Chinese media's new capacity to act as a liberal provider of public information than the presumed repressive ethos of the Chinese Party-state.

\section{Contextualizing the Incident}

Lu Deming’s fabulous fall from ‘exemplary scholar’ to ‘infamous man’ is inextricably linked to the new and contested status of prostitution as an object of governmental intervention in reform-era China. Prostitution constitutes a new phenomenon in the PRC in the sense that following their assumption of political power in 1949, the CCP embarked upon a series of campaigns that purportedly eradicated prostitution from the mainland by the late 1950s (Jeffreys 2004: 96). The extraordinary nature of this feat, irrespective of its actual validity, meant that the eradication of prostitution was (and still is) vaunted as one of the major accomplishments of the communist regime. Following Engels ([1884] 1972), the early CCP viewed the institution of prostitution as an expression of the exploited and denigrated position of women under capitalism- 
patriarchy, and hence as incompatible with the desired goals of building socialism and establishing more equitable socio-sexual relations. Since the early 1980s, however, governmental authorities in China have acknowledged that the phenomenon of prostitution has not only reappeared on the mainland, it also constitutes a widespread and growing problem, as evidenced by the proliferating body of Chinese prostitution law.

The re-emergence of prostitution as an object of governmental intervention in the PRC is usually presented as being historically coincident with the introduction of Deng Xiaoping's economic reforms and Open Door Policy in December 1978, and thus the shift from a planned centralized economy to one based on market mechanisms. Although recent studies demonstrate that the disappearance of prostitution under the Maoist regime was far from complete (Hershatter 1997: 331-3), it remains the case that the subject of prostitution did not exist as a serious object of governmental concern for a period of nearly three decades. When the PRC's first Criminal Law and Criminal Procedure Law came into force on 1 January 1980, only two Articles dealt directly with the subject of prostitution. Articles 140 and 169 of that Law banned all third-party attempts to profit from the prostitution of others, but made no explicit reference to the activities of firstparty participants in the prostitution transaction, or those who are usually referred to in the English-speaking world as prostitutes or sex workers and their clients (The Criminal Code of the People's Republic of China 1982: 2, 62, 69). The prostitution transaction only became a distinct object of legal classification in September 1991, following the promulgation of the Decision on Strictly Forbidding the Selling and Buying of Sex (hereafter the 1991 Decision), which was issued in conjunction with the Decision on the Severe Punishment of Criminals Who Abduct and Traffic in or Kidnap Women and Children (Quanguo renda changweihui et al. 1991).

In keeping with the new governmental rationale of the reform era, or the growing conviction that 'the market economy is a legal-system economy' (Chen 1996: 4), the 1991 Decision aimed to provide a legal basis for police-led campaigns against the rapid expansion of prostitution throughout China's new and burgeoning hospitality and service industry, chiefly by supplementing the limited reference to prostitution in the PRC's first 
criminal code. During the Maoist period (1949-76), the formal legal system fell into disrepute as a tool of class-based oppression and was replaced by the Chinese system of administrative and Party disciplinary sanctions (Starr 2001: 204-19). This latter system, under the auspices of the Chinese public security forces, was used to police the activities of those who were deemed to have committed social offences or political 'errors', but whose criminal liability was not deemed sufficient to bring them before the courts. Following the visible resurgence of prostitution in the early 1980s, therefore, the legal control of 'women who sold sex' (maiyin funü) and 'men who bought the services of illicit prostitutes (piaosu anchang) was effected on the basis of provincial rulings and localized policing initiatives until the introduction of the 'Regulations of the People's Republic of China on administrative penalties for public security' (1986) in January 1987 (hereafter the Regulations). Article 30, in Chapter 3 of the Regulations, states that it is forbidden to sell sex and have illicit relations with a prostitute, to introduce others into prostitution, and to provide accommodation for the purposes of prostitutional sex; and that offenders shall be detained for a maximum of 15 days for investigation, given a warning, made to sign a statement of repentance or given re-education through labour ${ }^{2}$ according to relevant regulations, and may be concurrently fined a maximum of 5,000 yuan (ibid.). The 1991 Decision extends these regulations by introducing a system of sanctions against any person who takes advantage of their work-based location in the hospitality and service industry to organize, force, facilitate, or introduce other persons to participate in prostitution (Quanguo renda changweihui et al. 1991). However, it keeps the prostitution transaction under the purview of the Chinese system of administrative and Party disciplinary sanctions by stipulating that sellers and buyers of sex should be handled according to Article 30 of the Regulations (ibid.).

The fundamental objective of the emerging body of Chinese prostitution law—to render the new kinds of recreational habits that have emerged in reform-era China open to governmental programmes of corrective intervention-have since found concrete

\footnotetext{
${ }^{2}$ Re-education through labour refers to a controversial set of administrative measures that provide for the compulsory reform through labour of those who have violated laws or regulations but who are not deemed to have committed a criminal offence. In the case of those deemed to have committed serious prostitutionrelated offences, this may involve forced detention for moral and legal education for a period between 6 months and 2 years.
} 
expression in the PRC’s revised Criminal Law of 1997 and the 1999 'Regulations concerning the management of public places of entertainment' (hereafter the Entertainment Regulations) (Zhonghua renmin gongheguo guowuyuan 1999). As with the 1991 Decision, Article 361 of the revised criminal code aims to restrict the conditions that contribute to the formation of a prostitution industry by introducing a system of controls over places of leisure and entertainment, and the people who own, manage, or work within them. Article 362 extends this concern by stating that hospitality and service industry personnel who leak information about prospective police investigations into the existence of prostitution activities in their work unit ${ }^{3}$ will be convicted for obstructing the course of justice (1997 Criminal Code of the People's Republic of China 1998: 187-8). However, if the revised criminal code registers a strong objection to the institution of prostitution, it still does not actively criminalize the behaviours of first-party participants in the prostitution transaction, with the notable exception of clauses relating to sex with minors and the premeditated spread of sexually transmittable infections (STIs) (Article 360, ibid.).

The Entertainment Regulations reiterate the provisions outlined in the 1997 Criminal Law by forbidding all forms of commercial sex-related activities in places of leisure and recreation, including the provision of 'accompaniment' or 'hostess-style' services, which have become a known front for prostitution activities in China (Zhonghua renmin gongheguo guowuyuan 1999). To support this ban, the Entertainment Regulations aim to restrict the available pool and turn-over of labour within the hospitality and service industry by reinforcing the long-standing stipulation that all personnel must possess a residency permit, or a temporary work and residency permit, and hence be 'known' to the local police. ${ }^{4}$ The Entertainment Regulations further aim to control the existence of

\footnotetext{
${ }^{3}$ During the Maoist period, and for some time after, the majority of urban residents in China were attached to a work unit, which is an enterprise or institution that provided comprehensive care for its employees, in the form of housing, education and health care. Restrictions on labour mobility to suit the requirements of a centralized planned economy meant that most urban Chinese spent their entire life in a given work unit and hence were part of a closed community, see Bray (2005).

${ }^{4}$ During the Maoist period, Chinese citizens were geographically fixed to their place of abode, usually their work unit, in order to suit the requirements of centralized planning. This system was twinned to a system of policing. The opening of China's labour markets in the era of economic reform required mobility and therefore undermined the basis of all Chinese policing — the geographically fixed population-since 1949. Hence efforts to combat crime and public order problems in present-day China often turn on attempts to
} 
corrupt and illegal management practices by reinforcing a system of commercial licensing and fair-pricing procedures; and by stipulating that any member of a relevant government department who is found to be directly or indirectly involved in the running of recreational enterprises will be penalized (ibid.).

Despite this veritable explosion of legislation, prostitution businesses and practices continue to proliferate throughout the PRC; hence, just as the phenomenon of prostitution has emerged as a new object of governmental concern, so too have questions concerning the most appropriate nature of its regulation. Whilst acknowledging the 'wellintentioned' nature of the CCP's historical condemnation of the prostitution industry, many commentators maintain that the existence of prostitution in China today is a reality (albeit perhaps an unhappy one) that governmental authorities should acknowledge by abandoning the ineffective policy of banning it. As they argue, the existence of local government collusion, combined with the ongoing demand for, and supply of, prostitution services, means that police-led campaigns against the sex industry have limited efficacy. Venues close during the campaign period, only to re-open once the campaign season is over; while the women who work in such venues simply go home to visit their families, move to more secure venues, or reinvent themselves as 'legitimate workers' going under the title of DJs, waitresses and so forth (Zheng 2004: 80-108). Concomitantly, although campaigns aim to eliminate an exploitative industry, they aggravate the difficulties faced by many women-in-prostitution by limiting their capacity to earn a livelihood, and forcing them to rely on the protection of third parties to evade police apprehension (Shi (n.d.)). Compounding these problems, the practice of fining minor prostitution offenders, rather than detaining them for police-funded re-education, has become a way in which the Chinese police can generate much-needed finances, thereby contributing to the pernicious problems of police corruption and arbitrariness (ibid.). Consequently, many commentators conclude that the PRC's ban on prostitution should be abandoned in favour of a more tolerant approach.

revitalize the mechanisms that rendered local populations 'visible' to the Chinese police during the Maoist era, such as household registration and work permits. 
An increasing number of commentators contend that China's governmental authorities should acknowledge the existence of prostitution by shifting towards a policy of decriminalization. As with the pro-sex work lobby of the international feminist movement (Jeffreys 2004: 70-95), some argue that decriminalization constitutes a preferable policy because it will not only enable women-in-prostitution to become selfemployed, thereby freeing them from exploitation at the hands of corrupt police, brothel organizers and pimps, but also facilitate the implementation of safer sex and HIV/AIDS prevention programs (Li Yinhe cited in Ai and Li 2001; Shi (n.d.)). Adding that prostitution is a mala prohibita or victimless crime, they contend that decriminalization will also enable China's public security forces to direct their limited resources at the more serious problems of organized crime and human trafficking, and simultaneously reduce prostitution-related corruption and abuse on the part of the police (ibid.).

Decriminalization is usually differentiated from legalization in that it means retaining government controls over the organization and facilitation of prostitution businesses, whilst removing government restrictions on the prostitution transaction, understood as the unremarkable, private exchange of sex for money between two consenting adults. In the context of China, it means removing the prostitution transaction from the purview of the Chinese system of administrative and Party disciplinary sanctions.

Other commentators similarly support a shift towards decriminalization; but, as with the policy adopted in Sweden (Ekberg 2004: 1187-218), they contend that China's governmental authorities should turn a 'blind-eye' to the activities of female prostitutes, whilst making it a punishable offence to obtain casual sexual services against payment (Zhu 2003). As with feminist NGOs who lobby for the abolition of prostitution (Jeffreys 2004: 70-95), this strategy is supported on the grounds that it will not only help to ameliorate the exploitation that is experienced by many women-in-prostitution, but also further the goal of abolition by placing the moral and legal responsibility for prostitution on the male side of demand. This proposed strategy is garnering support in China due to the revelations of police-led campaigns against prostitution and illegality conducted during the 1990s. These campaigns highlighted both the collusion of government officials in the running of prostitution businesses, and the widespread expropriation of public 
funds by male cadres to wine, dine and buy the services of female sellers of sex in entertainment venues (ibid.: 173). Hence, some commentators now aver that the punitive emphasis of China's prostitution controls should be directed towards those who buy sex and organize prostitution, especially government officials and law enforcement agents who do so (Zhu 2003).

In keeping with the programmatic and governmentalizing logic of Chinese campaignstyle policing, the exposure of links between governmental corruption and commercial sexual activities was promptly translated into calls for the formulation of further campaigns and new legal measures to combat such problems. In 1997, along with the promulgation of the revised criminal code, the Discipline Inspection Commission of the CCP issued a set of regulations designed to penalize Party members for their involvement in prostitution-related activities. Article 132 of the 'Communist Party discipline regulations' (1997: 15-16, hereafter the Disciplinary Regulations), under the heading 'Mistakes that seriously violate socialist ethics', states that any Party member who has sexual intercourse with others by 'using their powers, their superior or senior positions, seduction, cheating, or other means, will be dismissed from their Party posts'. Article 134, under the heading 'Mistakes that violate social administrative procedure', states that any Party member who engages in prostitutional sex, who forces, introduces, urges, entices, allows, or harbours others to engage in prostitution sex, or who purposely provides convenient conditions for others to engage in prostitutional sex, will be dismissed from the Party. And, Articles 135 and 136 outline penalties for cadres who engage in other forms of commercial sexual activities, and who fail to report the existence of commercial sexual activities in their place of work (ibid.). In doing so, the Disciplinary Regulations signify that the CCP's much-vaunted goal of tightening up Party discipline and wiping out corruption intimates that government officials and bureaucratic entrepreneurs ${ }^{5}$ are not above the law. They demonstrate that the conduct of

\footnotetext{
${ }^{5}$ The term 'bureaucratic entrepreneur' is used by Lance Gore (1999: 30) to refer to those 'party-state officials who are directly engaged in business activities and other activities aimed at promoting economic expansion'. Unlike cadres under the pre-reform command economy, who were primarily implementers of the state plan and other Party directives, bureaucratic entrepreneurs are expected to perform their political duties and take initiatives in the marketplace.
} 
government, not just the conduct of the governed, has become a renewed object of concern in present-day China.

Following the introduction of these measures, the Chinese media has publicized numerous cases of government officials being convicted and disciplined for abusing their positions and using public funds to keep 'mistresses', patronize prostitutes and to buy the 'company' of women in entertainment venues (e.g. 'Guangdong court judge sacked for hiring prostitutes’2000). In turn, the revelations of recent and more vigorous anticorruption campaigns, particularly the suggestion that more than 95 per cent of highranking officials who accept bribes and embezzle public funds either exchange favours for sex, keep a mistress, and/or hire the services of female sellers of sex, has led to calls for harsher penalties (Dai and Lu 2000). Specifically, they have prompted widespread media debate over the so-called new phenomenon of sexual corruption and generated arguments to the effect that the criminal code should be amended to penalize the activities of Party members and government employees who accept or solicit a bribe in the form of sexual services (ibid.).

In sum, Lu Deming's fall from 'exemplary scholar' to 'infamous man' owes much to the shifting parameters of China's prostitution controls. Lu was stripped of his Party membership, teaching responsibilities, and professorial privileges, after it came to the attention of his work unit, Fudan University, that he had been investigated and fined by the Chinese police as a buyer of sex. According to media reports, the police first became aware of Lu when he was named as a 'client' in an oral testimony provided by an apprehended female seller of sex. Lu was subsequently taken to the Yangpu District police station in Shanghai for questioning, where he signed a statement of repentance, received a warning, and paid a fine. In keeping with Chinese public security procedures, Lu's family members and relevant authorities at Fudan University were notified of his apprehension, a factor that ultimately led to the loss of his Party membership and professorial privileges. Given that Lu was sanctioned in accordance with the existing body of Chinese prostitution law, why did the Incident attract such widespread controversy? 


\section{Publicizing the Incident}

Although the nature of the Incident attracted speculative commentary from opinionholders on the Internet commencing in late August, the details of the case only became the focus of national controversy following the publication of an official interview-cumstatement that Professor Shi Lei, Head of the Publicity Department of Fudan University's Communist Party Committee, gave to a Dongfang (the Orient) website reporter on 5 November 2004, and the subsequent release of a written statement by Lu Deming on 7 November 2004. The transcript of Shi Lei's statement bears citing in full for three reasons. First, the unprecedented nature of such a media release makes it an interesting document in its own right. Second, it highlights the new role of website commentary in obliging the disciplinary apparatuses of the Chinese Party-state-in this case, the parallel organizations of the Party Affair Office and administrative committees at Fudan University - to account for their actions. Shi's statement counters website suggestions that relevant authorities had forced Lu to resign (i.e., leave) the University, both by rejecting that charge, and also by referring to the perceived 'serious' nature of the case and the ultimately 'lenient' manner of its handling. Finally, it reveals the existence of tensions between the historical role played by Party supervisory organs in ensuring that individuals abide by the law, observe public morality, and practice self-cultivation, and the emergence of a new and competing conception that the independent media is a more appropriate guardian and judge of Party and individual behaviours. Thus Shi counters website accusations of an 'official cover-up', and hence lack of freedom of public information in China, by intimating that the actions of relevant authorities were motivated by a desire to protect the broader interests of the scholarly community at Fudan, and the rights to 'privacy' of an individual who had admitted the errors of his ways.

Reporter: Is it true, as websites say, that Lu Deming was involved in buying sex?

Shi: Yes. The incident came to police attention in August and they called him in for investigation and fined him. 
Reporter: How has the University dealt with the incident?

Shi: We first gave him education and help. The university-level Party Affair Office and Office of Discipline Inspection Commission, Supervision and Auditing, and the faculty-level Party Affair Office, called him in for a talk. The Communist Party Committee then called him in for a special meeting to discuss the incident. Lu was punished according to Party disciplinary regulations and administrative procedures. The Discipline Inspection Commission took away his Party membership; and the University Chancellor's Meeting dismissed him from his post as Dean, but allowed him to stay on at the University under probation. We think this punishment is appropriate. It is serious, but also gives him the opportunity to reform. In terms of Lu's expertise, he can still do research and other work at the University and he has been provided with the opportunity to reform. In the short-term, however, he is not allowed to lecture or supervise post-graduate students.

Reporter: What does Lu Deming have to say about this?

Shi: He has admitted his error and regrets it. He has transgressed morality and committed a basic mistake. He is happy with the Party decision but unhappy with the University's decision to dismiss him from the position of Dean. He asked for a review of this decision. A review took place and upheld the original decision. Website commentators suggest that Lu has resigned and left Fudan. This is not the case: he is still at Fudan and has not tendered his resignation.

Reporter: What do you think of the Lu Deming Incident?

Shi: Of course we feel bad about it. Lu did his training at Fudan. He is an intellectual and a remarkable scholar. The incident has damaged the reputation of Lu Deming and Fudan University, as well as its various teaching teams. We need to give serious consideration to the following issues: how should Party groups conduct political and moral education for scholars, young ones in particular; and how do we promote self-restraint, self-discipline and good study habits, in a university setting that is characterized by a plurality of members and values?

Reporter: Why wasn't this incident reported to the public immediately? Shi: Because the details of the incident and how it should be dealt with had not been determined. We had to be careful in terms of retaining the credibility of the University. We did not want to hide anything from the public, but there is no need to make the moral failures of an individual public knowledge. We aimed to protect an individual who is willing to reform.

As Head of the Publicity Department of Fudan University's Communist Party Committee, I would like to add my own personal comments on the behaviour of the media. Prior to our public statement, some mainstream media made cautious comments on the subject. Unfortunately, other media reported rumours in an irresponsible fashion and made up stories. We call on the public to stop inventing stories and blowing this incident out of proportion. We should try to support and respect teachers and give Lu Deming the opportunity 
and environment to reform himself. We also should not cause further harm to his innocent family members (cited in He 2004, trans. E. Jeffreys).

Two days after Shi Lei gave this interview, Lu Deming released a written statement, the transcript of which is as follows:

My life has been agony of late. As the involved party, and an intellectual, I want to make the following declaration in order to clarify matters and prevent harm to others.

1. I am willing to admit my errors but do not want to be treated unfairly

1.1 I met the other party in the 'Rongshi [teahouse]'. I made this mistake in February 2004. At the time, the other party had no work, was not studying and had a hard life. My mistake lay in sympathizing and offering help and I lost morality. I broke contact once I realized my mistake and have not been in touch since. I have received two telephone calls and numerous text messages demanding blackmail money.

1.2 The police detained me on 12 August 2004. They wanted to take down my confession or testimony during investigation with regard to a case. I did not fully understand the seriousness of the mistake I had made or the nature of the incident. When a police officer indicated that s/he would conceal my name and work unit, I decided to cooperate and signed a statement. Afterwards, I received a public security warning and paid a fine.

2. I am willing to accept personal responsibility, but do not intend to shame my family, relatives and colleagues.

2.1 My moral mistake and my family life are two separate issues. I am grateful for the support and forgiveness of my family and friends following this incident. My sincere apologies for the harm it has caused them.

2.2 My mistake has had a negative effect on Fudan University. My apologies to lecturers, colleagues and students of the University.

2.3 My mistake had nothing to do with my professional entitlements, including those with my work unit [Fudan] and other legitimate work positions. My apologies to colleagues who have been affected.

2.4 I would like to thank and apologise to all those members of the public who have offered me their care, sympathy, support and criticisms.

3. I am willing to accept punishment, but hope that punishment will be reasonable and lawful.

3.1 On 1 September 2004, Fudan University announced the suspension of my employment pending investigation. I then immediately took responsibility and applied to resign but agreed to stay until the completion of disciplinary procedures. I submitted my proposed resignation from the position of Dean of the School of Economics and as a teacher at Fudan University on 2 and 16 of September, respectively.

3.2 I have applied for an administrative review of the disciplinary actions taken against me because the evidence that was presented to determine those actions is not convincing. 
I have learnt from my mistake and will review and learn from that experience. I hope the public will calm down soon ('Fudan jingji xueyuan...' 2004, trans. E. Jeffreys).

Lu Deming's statement is also unprecedented for three different reasons. First, it is clearly a public confession or apology in that Lu implies he admits 'the error of his ways', but it can also be read as a public legal defence since it intimates that he is the 'victim’ of overly punitive sanctions. Specifically, the statement implies that noble as opposed to base desires motivated Lu's actions; and that he was subsequently victimized by threats of blackmail from unspecified parties. ${ }^{6}$ Second, it intimates that a lack of professionalism and confidentiality on the part of the Chinese police-their perceived failure to explain due process, and respect some normative distinction between the public and private realms - is responsible for the shame brought upon Lu's family and colleagues. Finally, the statement implies that the faulty evidentiary procedures of the Chinese police have led relevant authorities at Fudan to overstep their allocated supervisory roles, resulting in Lu's unfair dismissal from his teaching and administrative positions. At the same time, the issue of whether Lu resigned from any of these positions remains unclear, since he was retained at the University as a government employee.

Irrespective of Shi and Lu's respective calls for 'media calm', the release of these two statements had the documented effect of turning the Incident into a nationwide scandal. One reporter claims to have counted 8,800 opinions opposing the governmental handling of the Incident on Internet chat-rooms immediately following the publication of Shi's statement (Yu 2004). Conversely, following the release of Lu's statement, other commentators pronounced that the punishments meted to Lu Deming were entirely appropriate and constituted an important victory in the ongoing fight against prostitution and corruption. Hence, efforts to affirm and question the rationality of Party-state

\footnotetext{
${ }^{6}$ It is not possible to ascertain from Lu's statement whether the woman involved in his apprehension had attempted to blackmail him. Letters demanding money otherwise an individuals alleged involvement in prostitution will be made public knowledge are a common 'confidence trick' in the PRC. These letters are sent arbitrarily to government employees and are couched along the lines of 'dear brother, I have fallen on hard times since I last saw you in $\mathrm{x}$ venue and $\mathrm{x}$ circumstances, please send $\mathrm{x}$ money to $\mathrm{x}$ bank account to ensure that the nature of our former relationship is kept secret. I say 'arbitrarily' since the originals of such letters that I have seen were sent to women with masculine sounding names. In keeping with advances in technology, text-messages may constitute another form of 'confidence trick'.
} 
apparatuses, articulated within the new spaces for dissenting opinion that now inform the global Chinese media (e.g. 'Fudan dean resigns amid sex scandal’ 2004), ensured Lu’s transformation from a virtual 'nobody' into a notorious national figure.

\section{Debating the Incident}

Media coverage of the Incident following the release of Shi Lei’s and Lu Deming's respective statements reveals the existence of living tensions in present-day China between what might be described as liberal and Maoist approaches to governance and the law, and associated conceptions of the 'public' and 'private' realms, the role of the media, and the nature of public intellectuals qua professionals and qua moral leaders. Drawing on liberal constructions of the appropriate relationship between sex and politics, critics of the governmental handling of the Incident maintain that sex between consenting adults is a private matter, and therefore an inappropriate target of governmental intervention, even when it is characterized by commercial exchange (Ji 2004; Yu 2004). While concurring with the official assessment that Lu's actions as an individual were morally reprehensible, they insist that knowledge of his activities should have remained a private affair, and that he should not have been dismissed from his administrative positions at Fudan, because he was not charged with taking advantage of his position or using public monies to buy sex ('Is a teacher’s sexual exploits public domain?’ 2004). Critics therefore conclude that Lu is a casualty of the Party-state's inability to separate 'the law' from 'traditional morality' and its concomitant failure to comprehend that the governance of sexuality is a matter of individual choice (Ji 2004; Yu 2004). Viewed in relation to the body of Chinese prostitution law, this conclusion suggests that engagement in the 'voluntary' prostitution transaction should be tolerated, i.e., removed from the purview of the Chinese system of administrative sanctions, even as it implies continued support for the popular contention that corrupt government officials who engage in illicit sexual acts should be subjected to harsher legal sanctions and public shaming.

Apart from questioning the PRC's ban on 'consensual' prostitution, critics of the governmental handling of the Incident aver that Lu became a victim of overly severe 
penalties due to the false presumption that teachers should set a good example by leading a life of impeccable moral integrity, thereby encouraging the erroneous conflation of individual and professional behaviours (Yu 2004). Noting that even former professors at Fudan University did not believe that Lu's actions compromised his academic credentials, they argue that the relevant authorities had no right to penalize Lu Deming by taking away his professorial privileges (Niu and Chen 2004). Somewhat ironically, critics fail to note that relevant authorities at Fudan presumably shared this sentiment, since Shi's statement indicates that Lu lost his teaching and administrative posts but was retained on probation at the University in a research and consultant capacity. Given that Chinese educators are bound by the Teacher's Law to provide a good example to students by observing the laws and moral customs of the PRC (Article 8, Zhonghua renmin gongheguo jiaoshifa 1993), it could be argued that the relevant authorities exercised some degree of clemency. Certainly, other commentators suggest that the governmental handling of the Incident was far too lenient, and hence could be part of a broader ‘corruption cover-up’ (Xue 2004).

In short, public expressions of sympathy for Lu Deming are usually couched in terms of a critique of the punitive nature of Fudan's ruling, both for penalizing a form of behaviour that arguably should be subject to moral self-regulation rather than overt governmental intervention, and for being an 'internal' decision based on the Chinese system of administrative and Party disciplinary sanctions. As demonstrated above, the regulations pertaining to prostitution in the latter system are not internal; they are publicly available. However, the issue at stake for critics here is whether Party committees possess the legal authority to adjudicate on matters of sex and professionalism, given China's reform-era shift to a 'rule of law' and associated efforts to separate Party and government functions. Assessed from this perspective, Lu is a contemporary 'anti-hero' struggling to obtain a 'fair hearing' in a system that has no respect for individual rights and contractual employment guarantees, and no clear system for redress when those rights are abrogated.

Condemnation of the perceived severe handling of the Incident also turns on the conviction that the case only came to light due to the unprofessional and corrupt nature of 
the Chinese police, and hence should never have been pursued. As critics note, the police relied on the oral confession of a detained female prostitute to apprehend and convict Lu Deming as a 'buyer of sex' some six months after the alleged event (Chai 2004; 'Cong "Fudan jiaoshou piaochang an” zhong kan jingcha xingwei de "shicha”' 2004; Ji 2004). This practice, they continue, does not conform to the evidentiary procedures required of Western-style jurisprudence, even though the charges were supported by Lu's written statement of repentance. Adding to these problems, the police betrayed the 'implied' rules of privacy and confidentiality by informing Lu’s family and work unit of the particulars of his case. The issue here, which relates to accusations of arbitrariness, is that the Chinese police are bound by Article 34 of the regulations on administrative penalties to notify an offender's work unit when the particulars of a given prostitution case have been determined, so that work unit personnel can assist with their subsequent supervision. However, this stipulation is not always followed in cases relating to the fining of prostitute clients. This omission has led not only to accusations that the Chinese police exonerate male buyers of sex, whilst penalizing female sellers of sex, but also to accusations that they impose heavy sanctions on 'ordinary citizens' of both sexes, whilst the illicit activities of high-ranking government officials are kept 'secret' (Shi (n.d.)). Critics thus conclude that the governmental handling of the Incident is both punitive and hypocritical, given the documented existence of police collusion in the running of places of prostitution, and the widespread use of public money by corrupt government officials for the purposes of prostitution (Ji 2004).

Public sympathy for Lu Deming and, conversely, antipathy towards the Chinese police, led to media coverage of previous 'whoring professor cases' that purportedly vindicate Lu with reference to the problematic nature of Chinese policing. For example, on 16 April 1999, the Chinese police detained Huang Jianyong, a professor at an unspecified university in Hunan Province, for suspected participation in the prostitution transaction during a work-related visit to Taiyuan City, Shanxi Province, in October 1998 (Ouyang 2004). Like Lu, Huang was detained some six months after the alleged event and fined 5,000 yuan. Huang subsequently appealed his case and asked for the return of his money, claiming that he had committed no offence and had paid the fine simply to be released 
from the police station. After various investigations, none of which were decided in his favour, Huang sought legal aid and notified China’s premier economic newspaper (Jingji ribao) that the Taiyuan police were generating illicit revenue by detaining and fining buyers of sex, and their corruption was so engrained that they were even prepared to 'make up' such cases. Following higher-level investigations, the sum of 5,000 yuan was returned to Huang in August 2004 on the grounds that it was collected without sufficient supporting evidence. However, the relevant policing authorities refused to sign a statement indicating that he was not guilty of the original charges. Huang then went to court to try and clear his name, demanding a written apology, compensation and reinstatement of reputation, but the case was rejected. Critical commentators therefore conclude that the arbitrary nature of Chinese law and policing has left people like Huang, and, by extension, Lu Deming, with no avenue to claim redress for a 'made-up' prostitution case (ibid.).

Although critics use the principle of analogy to evoke sympathy for 'hard-done-by' prostitute clients, discussions of the problematic nature of China's prostitution controls suggest that Lu's status as an 'infamous man' can be traced to efforts to resolve rather than ignore such issues. This remains the case even though it is not possible to determine the extent to which Lu Deming's fate was determined by the nature of his personal relationships and connections at Fudan University. To extrapolate, on 1 January 2004, the PRC promulgated new regulations designed in part to curb the corruption and revenueraising tactics associated with the fining of prostitution offenders ('China reigns in brutal police tactics’2003). These regulations stipulate that on-the-spot fines for prostitution offences are not permitted, unless the circumstances of the case are straightforward, in which instance the apprehending officer must provide the offender with a receipt detailing both the nature of the offence and the amount of the fine (ibid.). On-the-spot fines must not exceed 50 yuan in the case of an individual and 1,000 yuan in the case of a work unit (Shen and Tian 2003). The regulations further stipulate that suspects who are taken in for interrogation have the right to a hearing if they are fined more than 2,000 yuan; and that the police are not permitted to reveal publicly the private affairs of witnesses and suspects they interrogate (ibid.). The meaning of public in this instance is 
the general public, as opposed to an individual’s work unit, with the latter being positioned as a kind of 'greater private sphere'.

Viewed in this context, it appears that details of the Incident entered the public record due to the promulgation of additional regulations on 12 July 2004, which require the Chinese police to notify both an individual and also their family or work unit in writing when they are taken into custody for questioning (Gong’anbu ling di 75 hao 2004). The clarification of police procedures relating to the interrogation of suspects aims not to deny individual privacy, but rather to rectify the problems associated with a series of deaths flowing from police abuse and negligence in 2003. One case that attracted public outrage was that of a three-year-old girl who starved to death in her locked home after her mother, Li Guifang, was taken into custody for theft and drug addiction on 4 June 2003 (Miao 2003; 'Police jailed for kid's death’2004). Following her apprehension, Li was sent to a compulsory centre for drug rehabilitation in accordance with Chinese law. However, the attending police officers either failed to notify Li's relatives that she had been detained or failed to ensure that the child had been taken into care. The child was therefore left at home where she starved to death. The incident only came to light on 21 June, when the woman's neighbour noticed an unpleasant odour and called the local police, resulting in the discovery of the child's severely decomposed body (ibid.). Two policing officers were later sentenced to imprisonment for dereliction of duty. Details of Lu Deming's apprehension therefore entered a delimited form of 'internal' public record due to the standardization of police procedures, i.e., the obligation to notify others of his detention in order to ensure his personal safety, and the obligation to keep a record of the payment of fines for auditing purposes and potential appeals, as part of broader anti-corruption measures.

In consequence, whereas critical commentators attempt to vindicate Lu with reference to the perceived lack of transparency associated with Chinese law and Party-state apparatuses, commentators who support the governmental handling of the Incident tend to do so with reference to disciplinary practices derived from the Maoist era and the importance of fighting corruption. During the Maoist period, efforts to streamline the 
bureaucracy and ensure a 'proletarian style of work' placed considerable emphasis on the notion that people in positions of power and authority should act as a model for others by setting a higher standard than that which would be found in common practice (Mao 1942: 50). Party members and government employees were encouraged to achieve this exemplary state by practicing self-cultivation and submitting themselves to an ongoing process of criticism from others. In the process, they were viewed as replacing and surpassing the role of moral exemplars that was traditionally ascribed to intellectuals in China, chiefly due to their new and hard-earned possession of the superior insights afforded by Marxism-Leninism. Those who strayed from this model path were enjoined to confess their errors so that they could be welcomed back into the communist fold and 'cured' by accepting punishment and undergoing a process of reform, involving political and moral education, engagement in manual labour, and participation in criticism and self-criticism sessions (ibid.). Here is the basis of Shi Lei’s contention that the relevant authorities at Fudan University had helped Lu Deming by offering him education and the opportunity to reform.

Supporters of the governmental handling of the Incident reiterate this Maoist emphasis on the creation of the exemplary individual by asserting that Lu was treated fairly: he was punished for failing to meet his social obligations, but also was given an opportunity to redeem himself. Stressing his former status as a Party member, government employee and public persona, supporters of Fudan's ruling maintain that Lu's actions - in keeping with the treatment of corrupt government officials_-warrant harsher punishment than those meted to ordinary citizens (Zhou 2004). They also conclude that it is Lu's responsibility, as a presumed aspiring model citizen, to submit himself to a continuous process of public supervision via media criticism and monitoring of his behaviour.

Assessed from this perspective, Lu's documented questioning of the 'lawfulness' of Fudan's ruling is taken as a sign of his refusal to accept the consequences of his actions; and, as with the arguments mounted by critics of that ruling, it is deemed equivalent to giving the public the false impression that prostitution and corruption are acceptable social practices ('Is a teacher’s sexual exploits public domain?’ 2004). According to 
supporters of the governmental response, Lu's claim that his 'mistake' (fancuo) was predicated on sympathy for the 'other party' constitutes an attempt to excuse his misconduct by suggesting that he is a good Samaritan. Lu's ascription of 'noble' rather than 'base' motivations to his actions, they continue, is based on nothing more than his status as a famous economist, since the claim to be doing the woman in question 'a favour' would hardly be accepted if put forward by a manual worker (Guo and Chai 2004). Lu's written statement is thus dismissed as a hypocritical attempt to excuse his own actions and the existence of the sex industry. It is viewed as an expression of 'bourgeois right' insofar as it suggests that the punitive emphasis of China's prostitution controls should not fall on China's 'privileged elite'. Contrary to this implied view, many commentators aver that the punitive emphasis of China's prostitution controls should be directed predominantly if not exclusively at privileged (male) Party members and government employees, rather than towards certain subpopulations of 'the people' (i.e., the exploited and marginalized female prostitute) who already (as part of the collective labouring class) have unequal access to the social distribution of goods and resources (Shi (n.d.)).

Certainly, one commentator counters Shi Lei's call for the media to stop 'magnifying' the Incident by arguing that media silence is not an appropriate response; rather, further media investigation is necessary to help the involved party correct himself and also to prevent senior government employees from making similar mistakes (Xue 2004). In the opinion of this particular commentator, more rather than less coverage of the Incident is required since members of the public remain unclear on at least four counts. First, they do not know whether this is the first and only time that Lu Deming had bought sex. The implication here is that Lu (as a Party member) was potentially treated too leniently, since harsher penalties apply to repeat prostitution offenders. Second, members of the public have not been informed whether any other agents were involved (meaning organizers of prostitution, intermediaries, pimps and so forth), which implies that his lenient treatment might be part of a broader 'corruption cover-up'. Third, members of the public do not know whether public monies were involved or whether Lu was a recipient of sex-related bribery. Once again, this intimates that the details of the case might be 
more serious, as related to governmental corruption. Fourth, members of the public remain unclear as to what kind of work Lu is continuing to perform at Fudan University and hence the actual degree of his punishment. Thus, contrary to Shi Lei's suggestion that reporters are capitalizing on the 'prostitution details' of the case, and 'selling sex' in a different guise, the reporter concludes that the media should continue investigating the matter until all these questions are answered. Continued media coverage of the case is presented as being in the public interest, with the media being portrayed as an important tool for monitoring cadre behaviour and fighting corruption (ibid).

Reference to the problem of corruption helps to explain the controversy surrounding the governmental handling of the Lu Deming Incident and the nature of China's prostitution controls more generally. Although supporters of decriminalization usefully highlight both the problems associated with China's existing prostitution controls, and the potential benefits of such a policy shift for female sellers of sex, they also tend to ignore the male side of demand by assuming that male buyers of sex are individual citizens participating in an unremarkable 'private' transaction. This assumption is seriously challenged in the context of China by the demonstrated link between the demand for prostitution and the expropriation of public funds. Public outcry in this regard would suggest that calls to decriminalize the prostitution transaction in China are unlikely to result in immediate policy changes.

Concerns over the documented links between prostitution activities and various forms of corruption also help to explain a contradiction that appears in numerous accounts of the relationship between sex and government in China. This is the suggestion that the sexual affairs of ordinary citizens should be treated as a private matter of individual choice, but any transgression on the part of a senior Party member or government employee should be made public knowledge and handled severely. Thus, whereas critics of the governmental handling of the Incident aver that Lu Deming is an ordinary citizen and a casualty of the Party-state's continued adherence to outmoded forms of governance, supporters of Fudan's ruling insist that he is a privileged beneficiary of the state system who has failed to meet his social obligations. 
Last, but not, least, calls for the adoption of a more tolerant prostitution policy in China tend to elide the existence of local community objections. In China, as in the West, the objections of members of local communities to the institution of prostitution, combined with the perceived ineffectiveness of government controls, has resulted in various forms of community activism and vigilantism. Just as residents in 'red-light districts' of Birmingham, UK, publicized the names and vehicle license details of known kerbcrawlers (Home Office, UK, 2004), so too villagers in one area of Guangzhou Province recently posted the names and photographs of sellers and buyers of sex on public noticeboards in an attempt to curb localized street and brothel prostitution ('Guangzhou xiancun jiang maiyinpiaochangzhe shangbang gongshi’ 2003). Similarly, residents in the Daduqiao district of Chongqing Municipality urged local police to post the penalties for engagement in prostitution, and the names of apprehended prostitution offenders, on large public billboards over a highway overpass (Ding Xiangle et al. 2004). Contrary to the emphasis critics of the governmental handling of the Incident place on notions of individual privacy, therefore, there is some degree of community support for the expanded use of public shaming as a means to control the existence of prostitution businesses and practices.

\section{Conclusion}

Lu Deming is a casualty of the convergence of different disciplinary apparatuses, not strictly the Party-state's inability to separate 'the law' from 'traditional morality'. Although we are accustomed to two conflicting views of the media-it is generally conceived of in terms that reify 'information' either as propaganda or else as a positive contribution to individual freedom of choice_LLu's transformation from 'exemplary scholar' to 'infamous man' exemplifies the possibility that the socio-political role of the media cannot always be interpreted so simplistically. On the one hand, this case could be regarded as symbolic of a process of political reform whereby the media, granted increasingly liberal status with regard to certain issues, aims to safeguard the individual from unnecessary governmental intervention by exposing the problems with Chinese law, 
and also by comparing the CCP's allegedly old-fashioned approach to issues of sex and self-governance with that of the more 'tolerant' general public. On the other hand, the case could be regarded as indicative of the 'illiberal' nature of the modern media in that it turned the Incident into a question of individual subjectivity in a way that the Party-state never has and is incapable of doing. Media reportage effectively ensured that details of the case and the nature of its handling became available to a national and global public, rather than being restricted to the 'internal' public space of the work unit, with resulting pressure for Lu Deming to be rehabilitated on a national as opposed to local scale. Assessed from this perspective, Lu is a casualty of the Chinese media's new capacity to act as part of a disciplinary apparatus that extends beyond the purview of the Party-state via its claim to promote freedom of information. Taken one step further, and if Shi Lei's call for 'media calm' is taken literally, the possibility that the media and the Party-state may at times be involved in a certain amount of give-and-take with regard to tasks deemed necessary to maintain society's standards, and the concomitant possibility that in some cases the Party-state itself may be unable to intervene where the media (and its global auxiliary faction of netizen groupies) can, suggests a far more nuanced view of contemporary Chinese society and politics than is generally accepted.

\section{References}

1997 Criminal Code of the People's Republic of China (1998) trans. Wei Luo, Buffalo, New York: W.S. Hein and Co.

Ai Hua [Harriet Evans] and Li Yinhe (2001) 'Guanyu nüxing zhuyi de duihua’ [A dialogue on feminism], Shehuixue yanjiu, Beijing, Issue 4.

Bray, D. (2005) Social Space and Governance in Urban China: The Danwei System from Origins to Reform, Stanford; California: Stanford University Press. 
Draft only, not to be cited or circulated without the permission of the author, 10/5/2005. 9,889 wds.

Chai Huiqun (2004) 'Fudan jiaoshou piaochang an: benyi neibu jiejue de shijian heyi zhici?' [The case of the Fudan whoring professor: why did a case that was subject to ‘internal judgment’ become a public scandal?], Nanfang zhoumuo, 15 November.

Chen, A.H.Y. (1996) 'The developing theory of law and market economy in contemporary China', in Wang Guiguo and Wei Zhenying (eds) Legal Developments in China: market economy and law, Hong Kong: Sweet \& Maxwell Asia, 3-20.

'China reigns in brutal police tactics' (2003) People's Daily Online, http://english.people.cn/200309/10/eng20020910_124057.shtml (accessed 14 January 2005).

'Communist Party discipline regulations' (1997) Xinhua News Agency, Beijing, 10 April, trans. Selected World Broadcasts—China, 14 April, FE/2892 S2/1-18.

'Cong "Fudan jiaoshou piaochang an” zhong kan jingcha xingwei de "shicha”' [The 'Fudan University whoring professor case' exposes the problems with police investigations] (2004) posted on Institute of Sexuality and Gender website, Renmin University of China, http://www.sexstudy.org/article.php?id+1300 (accessed 22 December 2004).

Dai Yuanzhi and Lu Zhijian (2000) 'Jiang “xing huilu” zhiyu xingfa shecheng zhinei’ [Talking about putting ‘sex-related bribery and corruption’ within the effective range of the criminal code], Zhongguo qingnianbao, 15 December.

Ding Xiangle, Chen Liang, Sang Xiaoyu and Zhu Yan (2004) 'Tianqiaoshang gongbu maiyinpiaochangzhe xingming yin zhenyi' [Placing the names of prostitution offenders on an overpass bridge raises debate], Chongqing wanbao, 10 April.

Ekberg, G. (2004) 'The Swedish law that prohibits the purchase of sexual services', Violence Against Women, 10, 10: 1187-218. 
Draft only, not to be cited or circulated without the permission of the author, 10/5/2005. 9,889 wds.

Engels, F. ([1884] 1972) The Origin of the Family, Private Property and the State, New York: International Publishers.

'Fudan dean resigns amid sex scandal' (2004) Eastday.com, 2 November, http://www.chinadaily.cm/english/doc/2004-11/02/content-387731.htm, (accessed 22 December 2004).

'Fudan jingji xueyuan yuanyuanzhang Lu Deming fabiao shengming gongkai rencuo' [Lu Deming, former Dean of the School of Economics at Fudan University, issues a public statement admitting his mistakes] (2004) www.xinhuanet.com/newscenter/200411/09/content/2193202.htm, 9 November (accessed 10 January 2005).

Gong’anbu ling di 75 hao [Ministry of Public Security, Order No. 75] (2004) 'Gong'an jiguan shiyong jixu panwen guiding' [Regulations on interrogation procedures for public security organs], 12 July, http://www.chinacourt.org/flwk/show1.php?file_id+9551 (accessed 8 April 2005).

Gore, L.L.P. (1999) ‘The communist legacy in post-Mao growth’, China Journal, 41: 2554.

'Guangdong court judge sacked for hiring prostitutes’ (2000) Xinhua News Agency Bulletin, 26 September (C) Xinhua News Agency.

'Guangzhou xiancun jiang maiyinpiaochangzhe shangbang gongshi' [Xian Village in Guangzhou Province publicizes the names of prostitution offenders] (2003) Xinhua News Agency Online, 20 November, http://news.yninfo.com/picture/qita/2003/11/1069314182_8/index.html (accessed 6 January 2005). 
Draft only, not to be cited or circulated without the permission of the author, 10/5/2005. 9,889 wds.

Guo Jianguang (2004) ‘Jingji xuejia Fudan jingji xueyuan yuanzhang Lu Deming yin piaochang cizhi' [Lu Deming, Economist and Dean of the School of Economics at Fudan University resigns due to engagement in prostitution], Xinjingbao, 1 November.

Guo Songmin and Chai Haiqun (2004) 'Bo Lu Deming guailun: piaochang ke fupin ma?’ [Contrary to Lu Deming's strange views, whoring is not equivalent to a government programme for poverty relief], Nanfang zhoumuo, 12 November.

He Hui (2004) 'Fudan daxue xuanchuan buzhang jiu Lu Deming shijian da jizhe wen (quanwen)' [The Head of the public information and relations party committee at Fudan University speaks to a reporter about the Lu Deming Incident (complete transcript)], Dongfang Wang on rednet.com.cn, 6 November, http://news.rednet.com.cn/Articles/2004/11/630474.html (accessed 13 January 2005).

Hershatter, G. (1997) Dangerous Pleasures: Prostitution and Modernity in TwentiethCentury Shanghai, Berkeley, CA: University of California Press.

Home Office, UK (2004) Paying the Price: A Consultation Paper on Prostitution, July.

'Is a teacher’s sexual exploits public domain?' (2004) Beijing Review Online Forum, http://www.bjreview.com.cn/200449/Forum-200449.html (acessed 22 December 2004).

Jeffreys, E. (2004) China, Sex and Prostitution, London; New York: RoutledgeCurzon.

Ji Weidong (2004) 'Fabian "jiaoshou piaochang an”' [A legal analysis of the 'whoring professor case'], http://www.chineselawyer.com.cn/pages/2004-11-22/s25231.html, 22 November (accessed 22 December 2004).

Mao Zedong (1942) 'Rectify the party's style of work', 1 February, in Selected Works, Vol. 3: 50, http://www.marxists.org/reference/archive/mao/selected-works/volume3/mswv3_06htm (accessed 13 April 2005). 
Draft only, not to be cited or circulated without the permission of the author, 10/5/2005. 9,889 wds.

Miao Ye (2003) ‘Child’s death turns up heat on China’s police’, Asia Times, 28 June.

Niu Ying and Chen Xiaokang (2004) 'Zhuanjia renwei Fudan wuquan quxiao piaochang yuangzhang Lu Deming jiaoshou zige’ [Experts say Fudan University does not have the authority to cancel the professorial qualifications of Lu Deming, the whoring Dean], Falü jiaoyu wang, http://www.chinalawedu.com/news/2004\%5C11\%5Cli38501517371111140024560.html (accessed 10 January 2005).

Ouyang Xiaoqing (2004) 'Jingfang cheng Hunan moudaxue jiaoshou piaochang shouqu 5,000 yuan cai jiangqi fangzou' [A whoring professor from a university in Hunan is released after paying 5,000 yuan to the police], Qianlongwang, 24 November, http://mews.263.net/20041124/00446002.html (accessed 24 January 2005).

‘Police jailed for kid’s death’ (2004) Shenzhen Daily, 23 August.

Quanguo renda changweihui, xingfashi bianzhu, fazhi gongzuo weiyuanhui [Criminal Law Office and the Legal Council of the Standing Committee of the National People's Congress] (1991) Guanyu yanjin maiyin piaochang de jiuding he guanyu yancheng guaimai banjiafunü, ertong de fanzui fenzi de jueding shiyi [An Explaination of the Decision on Strictly Forbidding the Selling and Buying of Sex and the Decision on the Severe Punishment of Criminals Who Abduct and Traffic in or Kidnap Women and Children, Beijing: Zhongguo jiancha chubanshe.

'Regulations of the People's Republic of China on administrative penalties for public security’ (1986) Adopted at the Seventeenth Meeting of the Standing Committee of the Sixth National People's Congress, promulgated by Order No. 43 of the President of the People's Republic of China on 5 September 1986, and effective as of 1 January 1987, http://www.novexcn.com/admin_penalty_pub_security.html (accessed 14 January 2005). 
School of Economics, Fudan University (n.d.) 'Lu Deming', http://www.econfudan.cn.english/LuDeming\%20.htm (accessed 11 January 2005).

Shen Lutao and Tian Yu (2003) 'Maiyin piaochang gongan jiguan banan renyuan bude dangchang chufa' [Police officers should not issue on-the-spot fines when dealing with prostitution cases], Xinhua Online, Beijing, 8 September, http://online.cri.com/cn/773/2003-9-9/178@304475.htm (accessed 9 September 2004).

Shi Meitang (n.d.) ““Maiyinpiaochang” kefuo geiyu hefa diwei?’ [Should prostitution be legalized or not?], Law-China, http://www.law-china.com/15/cp150004.htm (accessed 3 September 2003).

Starr, J.B. (2001) Understanding China: A Guide to China’s Economy, History and Political Structure, London: Profile Books.

The Criminal Code of the People's Republic of China (1982) Translated and with an Introduction by Chin Kim, Littleton, Colorado: Fred B. Rothman and Co.; London: Sweet and Maxwell Limited.

Xue Keqin (2004) 'Jiaoshou piaochang buneng qingyi hua juhao’ [We should not put a full stop on the whoring professor case], Jiancha ribao, 10 November, p. 8.

Yu Zhenhua (2004) 'Daxue jiaoshou piaochang zao zhongfa heyi yinlai wangshang jiaoqu sheng' [The harsh punishment given to the whoring university professor attracts complaints on the Internet], www.qianlong.com/3317/2004/11/22/225@2385884.htm, 22 November.

Zheng, Tiantian (2004) 'From peasant women to bar hostesses: gender and modernity in post-Mao Dalian, in A. Gaetano and T. Jacka (eds) On the Move: Women in Rural-toUrban Migration in Contemporary China, New York: Columbia University Press, 80108. 
Draft only, not to be cited or circulated without the permission of the author, 10/5/2005. 9,889 wds.

Zhonghua renmin gongheguo guowuyuan [State Council of the PRC] (1999) Yule changsuo guanli tiaoli [Regulations concerning the management of public places of entertainment], Beijing: Wenhua chubanshe.

Zhonghua renmin gongheguo jiaoshifa [Teacher's Law of the People's Republic of China] (1993) Adopted at the Fourth Meeting of the Standing Committee of the Eighth National People's Congress, promulgated by Order No. 15 of the Chairperson of the People’s Republic of China on 31 October, www.moe.edu.cn/jyfg/laws/jyfgjsf.htm (accessed 2 March 2005).

Zhou Yun (2004) 'Jiaoshou piaochang jingshi zhishifenzi daodi xiahua' [The case of the whoring professor exposes the moral decline of intellectuals in China] www.xinhuanet.com/comments/2004-11/02/content_2166895.htm, 2 November (accessed 11 January 2005).

Zhu Jiaolong (2003) ‘Saohuang yinggai zhua jinü haishi piaoke?’ [Should campaigns against prostitution and illegality target the sellers or buyers of sex?], Nanfang dushibao, 2 December. 